Short Communication

\title{
Wilhelm Conrad Roentgen and Switzerland
}

Exhibition in the Museum of the History of Medicine

of the University of Zurich, May 18th to December 17th, 1995

Christoph Mörgeli

Wilhelm Conrad Roentgen was born on March 27, 1845 in the town of Lennep (today part of Remscheid in Nordrhein-Westfalen). His father, Friedrich Conrad, was a wealthy merchant and cloth trader in this important textile and industrial town; his mother, Charlotte Constanze, born Frowein, came from Amsterdam.

In 1848 Roentgen's parents moved with their only child to Apeldoorn in The Netherlands, 25 kilometres to the north-east of Arnhem. After primary and secondary school Wilhelm Conrad was enrolled in the Technical School of Utrecht from which, however, he was expelled for performing a harmless joke. After this he attempted to continue his studies as an auditor at Utrecht University. His schoolmate Carl Thormann from Rotterdam, whose family came from Berne, drew his attention to the fact that in Zurich students without a high school graduation certificate were eligible to enroll at the Federal Polytechnic (Eidgenössische Technische Hochschule).

\section{Education in Zurich}

With his friend Thormann, Roentgen moved to Zurich for the winter term 1865/66 after having sent the director of the Polytechnic an inquiry (in impeccable German) about his possibilities to study. An eye infection prevented him from arriving in time; the Polytechnic agreed to waive the entrance examination for the belated student on the strength of his good report. Roentgen enrolled in the mechanical-technical department and persued his

PD Dr. phil. Christoph Mörgeli, Konservator des Medizinhistorischen Museums der Universität Zürich, Rämistrasse 71, CH-8006 Zürich 

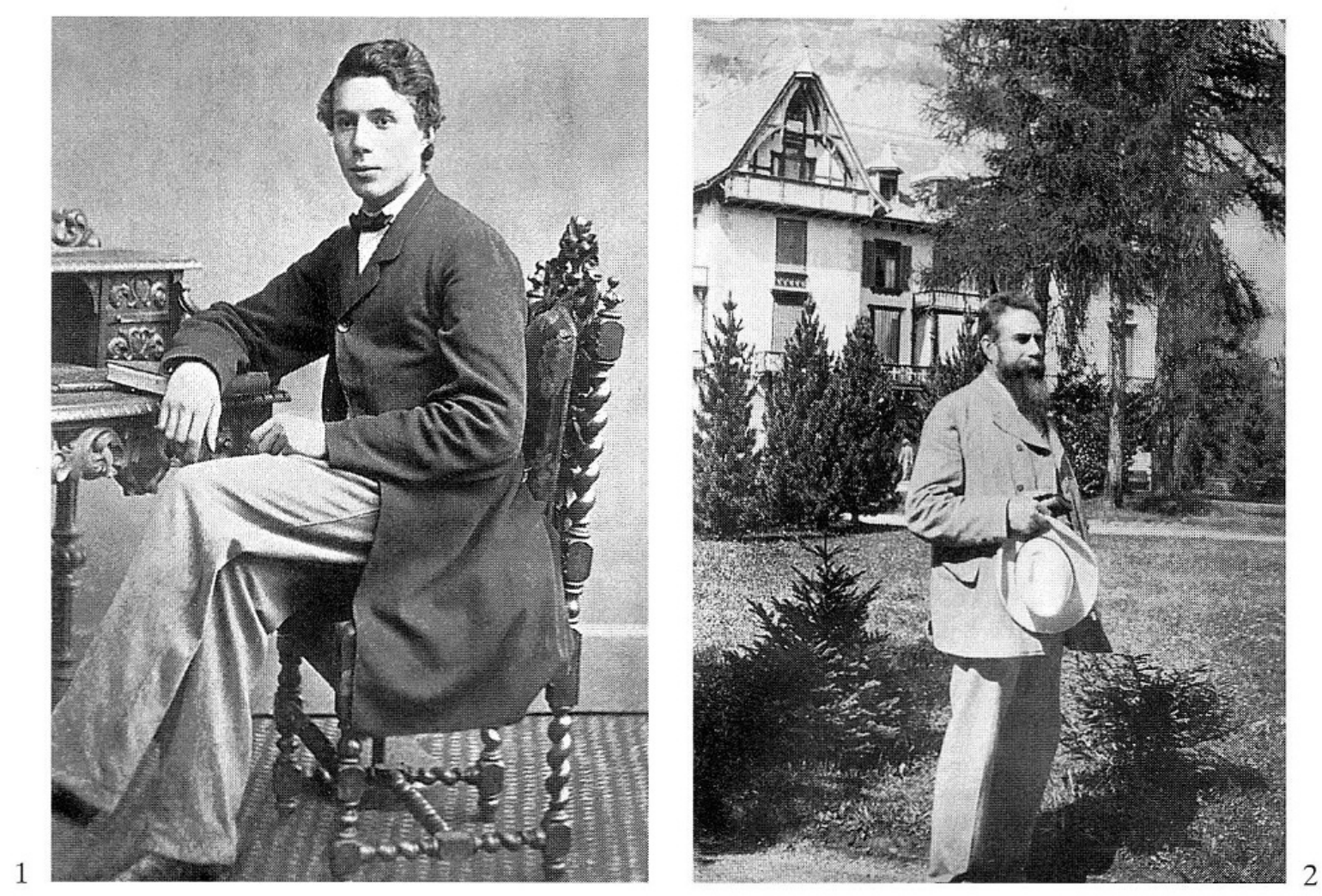

Fig. 1. Wilhelm Conrad Röntgen during his school years in Utrecht, around 1865 (German Röntgen Museum in Remscheid-Lennep).

Fig. 2. Wilhelm Conrad Röntgen in Waldhaus-Flims.

studies of mechanical engineering with enthusiasm and interest. At the time, the Polytechnic did not lead to the doctoral level. Therefore, Roentgen enrolled at Zurich University after having successfully earned the diploma in mechanical engineering in 1868.

Roentgen wrote his doctoral thesis with the Polytechnic professor of mechanics, Gustav Zeuner, and submitted it to the faculty of Philosophy of the University under the title "Studies on Gases".

There is no reliable proof as to where Roentgen's first dwellings in Zurich were. From November 1866 until he left Zurich in the spring of 1870 he had his lodgings in a room in the house of the widow Barbara Grebel-Fahrner on Seilergraben 7 .

In 1922, much to Roentgen's delight, the Swiss Association for Medical Radiology had a commemorative tablet attached to this building where he had had his student digs.

Many an anecdote of Roentgen's jolly student life seem considerably exaggerated. Nevertheless, his collection of photographs attests to his adoration for the actress Sitterding at the Municipal Theatre of Zurich, with whom he fell passionately and unhappily in love. 


\section{Berta Ludwig}

The public house "Zum Grünen Glas" in the street called Untere Zäune was patronized by theatre people, students, and professors. Johann Ludwig from Gotha was the owner of this public house. As a student he had taken part in the liberal rebellion in Göttingen, and since 1833 he was employed as a fencing teacher at the newly founded University of Zurich. Roentgen fell in love with Berta Ludwig, the second of the innkeeper's three daughters. Although she was six years his elder, they decided to get engaged. In January 1872 Roentgen married his Zurich bride in Apeldoorn.

\section{Academic Activity}

Polytechnic professor August Kundt encouraged Roentgen to concentrate on the study of physics. When Kundt took over as professor of experimental physics in Würzburg in the spring of 1870, Roentgen followed him as his assistant. Not having a highschool certificate he was not eligible to take his habilitation there. However, he made up for this in 1874 in Strassburg, where he now worked with Kundt. In 1875 Roentgen became professor of physics at the Academy of Agriculture in Hohenheim near Stuttgart, and it was only one year later that he became second physicist and senior lecturer in Strassburg, along with Kundt. In 1879 he was granted the chair of physics in Giessen. It was here that Roentgen established his name as one of the greatest experimental physicists of his time. In particular, his proof of Maxwell's predicted theory of "Shifted Current" (later called Roentgen Current) in 1885 brought him international recognition. In 1888 he became professor of physics at Würzburg University, whose rector he was in 1894 and where he discovered X-rays in 1895. Finally, in 1900, he was called to Munich University where he remained until his retirement in 1920.

\section{The Discovery of X-Rays}

Like many other physicists of his time, Roentgen did experimental research work with cathode rays at the physics institute in Würzburg. On 8 October 1895 , he discovered a new kind of rays (he named them X-rays) to which no one had paid any attention until then. The description of his discovery was so perspicuous and convincing that, try as they may, none of the many physicists from all over the world succeeded in adding anything new to the sub- 
ject in the 10 years that followed. By 1896 the treatise "On the New Species of Rays", had become a classic. In this treatise Roentgen proposes the fields in which X-rays would be mainly used in the future: medical diagnostics and indestructive testing of working materials. Although he could have protected his discovery by taking out a patent on it, Roentgen all his life refused the idea of making financial profit with his discovery.

On 23 January 1896 Roentgen presented his discovery before the Medical-Physics Association in.Würzburg. To conclude the presentation he Xrayed the famous anatomist Albert von Koelliker's hand. Zurich-born Koelliker turned to the enthusiastic audience and suggested that, in honour of the discoverer, X-rays be called Roentgen rays in the future. In 1901 Roentgen was awarded the Nobel Prize for physics in Stockholm.

The discovery produced an immediate wave of enthusiasm. The scholar Roentgen suddenly found himself the object of admiration, and being a rather quiet man, he found the upheaval about his person somewhat troublesome. He was flooded with letters from all over the world, from monarchs, statesmen, scientists, and also from numerous private persons. Roentgen sent the Zurich Association of Clinical Medicine, who had invited him in January 1896, a telegram in moving words, thanking them and reminding them that he had spent the best time of his youth in Zurich. The Association of Former Polytechnic Students of Zurich declared Roentgen an honorary member in 1896, as did the Schweizerische Naturforschende Gesellschaft (SNG) in 1897 and the Swiss Roentgen Association on the occasion of its foundation meeting in 1913. In 1896 Dr. and Mrs. Roentgen took part in the SNG meeting in Zurich where he also was the toastmaster for the evening entertainment.

\section{Holidays in Switzerland}

It was in 1873 that Dr. and Mrs. Roentgen spent their four-weeks summer holiday in the village of Pontresina in the Engadin (Grisons) for the first time. After that they returned to the hotel «Weisses Kreuz» in Pontresina from 1881 to 1913 almost every year. From 1891-1908 Berta Ludwig, Berta Roentgen's niece, accompanied the childless couple and was later adopted by them.

Roentgen enjoyed taking photographs of the Engadin landscape and went on a considerable number of mountain tours. A group of loyal friends (German and Swiss scientists) accompanied him regularly on these excursions, including the Zurich surgeon Kroenlein and the ophthalmologists Ritzmann and von Hippel. 
Before the opening of the Albula railway, the Engadin could only be reached by horse-drawn mail coaches. Those that could afford it hired a coachman to get to their destination and also to be taken on excursions in the surroundings. Emanuel Schmid from Somvix, became Dr. and Mrs. Roentgen's exceptionally reliable coachman, in whose future they took a personal interest. Later-on in life, Roentgen also became acquainted with Schmid's brother, the Bishop of Chur, Georg Schmid von Grüneck.

In order to become acclimated to the high mountain region, Dr. and Mrs. Roentgen often stayed in places of intermediate altitude, as for example in Waldhaus-Flims, on Rigi-Scheidegg or on Lenzerheide. In 1894 Roentgen visited the Engadin in the winter for the first time. During the winters between 1898 and 1912, the Roentgen family regularly spent their Christmas and New Year's holidays in the "Sport- and Posthotel Flüela" in Davos Village. From 1907 to 1912 they patronized the "Hotel Bellevue" in Cadenabbia on Lake Como in the spring holidays, and sometimes also Vitznau or Territet, on Lake Lucerne and Lake Geneva, respectively.

From the summer of 1913 to the summer of 1921, Roentgen was prevented from spending his holidays in Switzerland by political instability and war conditions in Germany. Time and again he expressed his longing for the Swiss high mountain regions, where he had spent so many a happy hour with his wife and his friends. He was eager to consolidate his contact with Switzerland and his Swiss friends, if only spiritually, by the reading of Swiss authors and frequently corresponding with his friends.

In 1921 his Swiss friends invited him for a trip to Switzerland. He spent two weeks in Pontresina and on Lenzerheide. In Zurich he visited the members of the Ludwig family whom he had been supporting financially for many years. During a second summer stay in 1922 he was a guest in Sils-Baselgia and once again on Lenzerheide.

\section{Roentgen in His Time}

Although Roentgen had hoped for a German victory in World War I, he spoke pessimistically of the development of the war. In 1914, under considerable pressure by the citizens of Berlin, he signed the notorious «Manifest» of the 93 German academics at the time of the German invasion of neutral Belgium and the destruction of Loewen. In later years he bitterly regretted this ill-considered political act. After the war he suffered inflation and the loss of his shares. In the first, rather unstable years of the Weimar Republic, Roentgen clearly took a stand against the rising anti-Semitism and National Socialism. 


\section{Berta Roentgen's and Conrad Wilhelm Roentgen's Death}

Since 1913 Roentgen's wife had suffered from kidney stones, and only by regularly taking increasing doses of medicine was she able to stand the pain. The ophthalmologist Woelfflin from Basel advised Pantopon combined with morphine. Wilhelm Conrad Roentgen gave his wife the injections several times a day for six years. Berta became addicted to morphine. The care Roentgen gave his wife was the main reason for his reduced social contacts, and he therefore gradually grew more lonely. Berta Roentgen died on 31 October 1919 after a terrible agony.

Wilhelm Conrad Roentgen died on 10 February 1923 at the age of 78 of a painless intestinal carcinoma from which he had suffered only two days prior to his death. His cremation took place at the Eastern Cemetery of Munich three days later, and only a few people were present. A little later Roentgen's ashes were transferred to his family vault at the Old Cemetery in Giessen where his parents and his wife had been buried.

\section{Literatur zum Zentenarium der Entdeckung der Röntgenstrahlen}

Beier, Walter: Wilhelm Conrad Röntgen. 2. überarb. Aufl. Leipzig, B. G. Teubner Verlagsgesellschaft, 1995, 135 pp.

Ellegast, H. H.; Kogelnik, H. D.; Strasser, E. (Hrsg.): Hundert Jahre medizinische Radiologie in Österreich. Wien/München/Bern, Verlag Wilhelm Maudrich, 1995, 318 pp.

Fölsing. Albrecht: Wilhelm Conrad Röntgen. Aufbruch ins Innere der Materie. München, Hansen, 1995,383 pp.

Glasser, Otto: Wilhelm Conrad Röntgen und die Geschichte der Röntgenstrahlen, 3. Aufl. Berlin, Springer-Verlag, 1995, 381 pp.

Heuck, Friedrich H. W.; Macherauch, Eckard (Hrsg.): Forschung mit Röntgenstrahlen. Bilanz eines Jahrhunderts (1895-1995). Berlin/Heidelberg/New York, Springer-Verlag, 1995, 682 pp.

Leicht, Hans:Wilhelm Conrad Röntgen. Biographie. München, Ehrenwirth Verlag GmbH, 1994, 193 pp.

Lossau, Norbert: Röntgen. Eine Entdeckung verändert unser Leben. Köln, VGS-Verlagsgesellschaft, 1995, 208 pp.

Rosenbusch, Gerd; Oudkerk, Matthijs; Ammann, Ernst; Becker, Hartmut: Radiologie in der medizinischen Diagnostik. Evolution der Röntgenstrahlenanwendung 1895-1995. Berlin, Blackwell Wissenschaft, 1994, 545 pp.

Schedel, Angelika; Keil, Gundolf: Der Blick in den Menschen. Wilhelm Conrad Röntgen und seine Zeit. München/Wien/Baltimore, Urban \& Schwarzenberg, 1995, 311 pp.

Thomas, A. M. K. (ed.); Isherwood, I.; Wells, P. N. T.: The invisible light. 100 years of medical radiology, Oxford, Blackwell Science, 1995, 109 pp. 